\title{
Ян Заневски
}

Wyższa Szkoła Finansów i Zarządzania, Białystok

Наталья Николаевна Нижнева

Белорусский Государственный Университет, Минск

Надежда Леонидовна Нижнева-Ксенофонтова

Белорусский Государственный Университет, Минск

\section{ПРОБЛЕМЫ ОБУЧЕНИЯ ВЗРОСЛЫХ ИНОСТРАННЫМ ЯЗЫКАМ}

\begin{abstract}
SUMMARY
Teaching English to adults

The work is devoted to the problem of andragogy - teaching foreign languages to adults. Modern achievements in the field of theory and practice of teaching foreign languages to this contingent are analyzed. The importance of creative approach and the actuality of this problem are emphasized. Extensive social-psychological description of adults is given. Intellectual functions of adults (thinking, attention, memory) are analyzed in detail. In conclusion, conditions and recommendations necessary for achieving the required aims and success in teaching foreign languages to this group of students are enumerated.
\end{abstract}

Key words: age, andragogy, typology of students, memory, thinking, attention

\section{STRESZCZENIE}

\section{Nauczanie języków obcych osób dorosłych}

Praca poświęcona jest wybranemu zagadnieniu andragogiki - nauczaniu - języków obcych osób dorosłych. Analizowane są dotychczasowe dokonania w zakresie teorii i praktyki nauczania języków obcych dorosłych oraz podkreśla się ważność i aktualność tego zagadnienia. 
Dana jest obszerna charakterystyka socjalno-psychologiczna osób dorosłych. Szczegółowo analizowane są intelektualne funkcje dorosłych (myślenie, uwaga, pamięć). W zakończeniu podane są warunki i rekomendacje niezbędne dla osiągnięcia zamierzonego sukcesu przy edukacji obcojęzycznej tej populacji „uczniów”.

Знание иностранного языка становится необходимой составной частью личной и профессиональной жизни человека в современном обществе. Усиливается тенденция изучения иностранных языков взрослыми с точной прагматической ориентацией на обеспечение коммуникации в сфере бизнеса, туризма, культурных и научных связей.

О признании необходимости владения иностранными языками в современных условиях свидетельствует статистика. По официальным данным в 15 европейских странах «старого» ЕС признаются в достаточной степени владеющими иностранным языком: 31\% населения в возрасте 55 лет и старше, 39\% - в возрасте от 40 до 54 лет, 52\% людей от 25 до 39 лет.

Начало формирования теоретических основ андрагогики ${ }^{1}$ как самостоятельной науки было положено в 1970-1980 гг. в работах американского теоретика и практика М. Ш. Ноулза, англичанина П. Джарвиса, поляка Я. Заневского, группы молодых ученых Ноттингенского университета, продолжено в работах русского исследователя С. И. Змеёва ${ }^{2}$. Андрагогикой выработано понятие о взрослом человеке как о лице, обладающем физиологической, социальной, нравственной зрелостью, экономической независимостью, жизненным опытом и уровнем самосознания, достаточным для ответственного самоуправляемого поведения ${ }^{3}$.

Взрослые - это особый контингент обучаемых, который характеризуется прагматическим отношением к образовательным услугам. Образование включается в общий контекст их жизнедеятельности. Образовательная среда зависит от их доминирующих интересов и потребностей. Это предъявляет особые требования к образовательным технологиям обучения взрослых, поскольку взрослый человек самостоятельно определяет цели учебной деятельности, выбирает формы, методы, средства и способы обучения, оценивает и корректирует результаты продвижения, осознает свои возможности

1 Андрагогика - наука, занимающаяся процессами образования и воспитания взрослых лиц.

2 Zob. J.Zaniewski, Podstawy nauczania języka rosyjskiego jako obcego pracowników nauki (medycyny). (Zasady, dobór językowy, etapy i formy), Białystok 1980.

3 Zob. Е. П. Рыжикова, Научно-педагогические условия изучения иностранного языка в системе андрогогики. Автореф. дисс. на соиск. уч. ст. канд. педагог. наук., Москва 2001. 
и свое место в осуществляемой деятельности ${ }^{4}$. В связи с этим, андрогогические принципы обучения применительно к иностранным языкам становятся особо значимыми и востребованными. Целью обучения аудированию и чтению - становится обучение пониманию; обучения общению и письму - умение выразить мысль так, чтобы она адекватно была понята собеседниками или читателями. Как правило, возможно, очень хорошее овладение навыками чтения, но не в достаточной степени овладение навыками и умениями общения.

Сформированность произносительных навыков является важным условием успешного общения. Формируются они интуитивно на разных этапах обучения, соединяясь с анатомическими процессами создания артикуляционной базы, а эта база окончательно создается к 8-му году жизни. В этот период артикуляционные навыки формируются легко, без труда и потом являются постоянными. У взрослых фонация создается с большим трудом, оказывается непрочной, а акцент является явлением постоянным. Вероятно, основная трудность в формировании фонематического слуха и фонологического сознания заключается в разнице фонологических и фонетических черт звуков родного языка и иностранного. Мы слышим не то, что фактически демонстрируется, а то, к чему привыкли на родном языке. Именно поэтому, при обучении взрослых, обучение слушанию с пониманием является очень важным этапом этого процесса.

Совсем другую картину имеем в синтактической области, в лексике, фразеологии и стилистике. Эти навыки и умения создаются сознательно, путем специального обучения и самоподготовки. Они динамичны, доступны в каждом возрасте. Менее доступны обучаемым в молодом возрасте.

Существующая методическая литература, в основном, содержит материалы для обучения иностранным языкам детей и молодежи (дошкольники, школьники, студенты). Контингенту изучающих иностранные языки взрослым - уделялось меньше внимания. Если даже появлялись отдельные

4 Zob. А. С. Локосова, Изменение мотивационно-иенностной сферы личности взросльх профессионалов в ходе обучения деловому английскому языку: на материале слушателей Президентской программы. Автореф. на соиск. уч. ст. канд. педагог. наук., Нижний Новгород 2006.

5 Под возрастом мы понимаем конкретную стадию биологического и социально-психологического развития личности. В жизни каждого человека мы выделяем: 1) возраст грудной - от 1 месяца до 1 года; 2) в. ясельный - от 1 года до 3 лет; 3) в. дошкольный - от 3 до 7 лет; 4) в. школьный - с 7 до 16-18 лет; 5) в. юношеский - от 16 до 20 лет у женщин и от 17 до 21 года у мужчин; 6) в. зрельй от 20 до 55 лет у женщин и от 21 до 60 лет у мужчин; 7) в. пожилой - от 55 до 75 лет у женщин и от 60 до 75 лет у мужчин; 8) в. стариеский - от 75 лет и старше. Zob. Энциклопедический словарь медицинских терминов, t. 1, Москва 1982, s. 217. 
публикации на эту тему, то они, пожалуй, имели фрагментарный характер. Тем не менее, в настоящее время в психолого-педагогической литературе накоплен определенный теоретический и эмпирический материал, раскрывающий особенности процесса обучения взрослых:

- психологические и интеллектуальные характеристики взрослого, как субъекта образования (Б. Г. Ананьев, А. Б. Брушлинский, С. Г. Вершловский, J. Zaniewski, Ю. Н. Кулюткин, С. Л. Рубинштейн, Г. С. Сухобская);

- особенности обучения взрослых иностранным языкам (В. М. Ботов, Н. Д. Гальскова, Г. А. Китайгородская, Ю. Н. Кулюткин, Н. В. Лесохина, Р. П. Мульруд, В. В. Сафонова, Г. С. Сухобская, И. А. Цатурова);

- факторы успешного продвижения человека в образовании на различных этапах зрелости (К. А. Абульханова-Славская, Л. И. Анциферова, А. А. Бодалев, Л. С. Выготский, J. Zaniewski, H. Komorowska, А. Маслоу, К. Роджерс, В. Франкл, К. У. Шайи и др.);

- вопросы саморазвития и самоактуализации личности (В.И. Андреев, М. В. Бородина, Ю. Н. Кулюткин, А. Markunas, Н. Н. Нижнева, М. Ноулз, К. Роджерс, В. В. Сериков, Г. С. Сухобская, И. С. Якиманская и др.) ${ }^{6}$.

Анализ научной литературы показывает, что практически отсутствуют работы, раскрывающие этимологию психологических барьеров, которые возникают у взрослых при изучении иностранного языка. Не структурированы условия и факторы, обеспечивающие преодоление или компенсацию психологических барьеров при овладении иноязычными навыками и умениями. Взрослому как субъекту учебной деятельности необходима определенная психологическая помощь для адаптации к ситуации обучения ${ }^{7}$.

Изучение научной литературы и практического опыта в области методики преподавания иностранных языков выявляет ряд противоречий, которыми объясняется неэффективность обучения взрослых:

1) зрелость личности взрослых обучающихся, их конкретные целевые установки в области изучения иностранных языков и авторитарный

6 Zob. Г. М. Бурденюк, Управление самостоятельной учебной деятельностью при обучении иностранным языкам. Автореф. дисс. на соиск. уч. ст. докт. педаг. наук., Йошкар-Ола 1999; А. В. Филатова, Дидактические условия реализации андрагогической поддержки взросльх обучения иностранному языку. Автореф. дисс на соиск. уч. ст. канд. педаг. наук., Йошкар-Ола 1999.

7 Zob. А. С. Локосова, Изменение мотивационно-иенностной сферы личности взрослых профессионалов в ходе обучения деловому английскому языку: на материале слушателей Президентской программы. Автореф дисс. на соиск. уч. ст. канд. педаг. наук., Ростов-на-Дону 2004. 
характер преподавания (субъектно-объектные отношения между обучающим и обучающимся);

2) наличие определенных личностных особенностей взрослых обучающихся, сформированность стилей познавательной деятельности и единая для всех программа и технология обучения без учета индивидуальных особенностей и профессиональных интересов субъектов учебного процесса;

3) разная степень сформированности мотивации и ее характер у обучающихся и отсутствие в содержании обучения компонентов, повышающих мотивацию и способствующих осознанию обучающимися своих потребностей в использовании иностранных языков в профессиональных целях ${ }^{8}$;

4) между востребованностью специалистами знания иностранного языка в современном обществе с учетом процессов глобализации и недостаточной работоспособностью технологий обучения взрослых иностранному языку;

5) между строгой регламентацией образовательного процесса в системе профессионального послевузовского образования и необходимостью учета индивидуально-типологических особенностей взрослых;

6) между традиционно ведущей позицией преподавателя в учебном процессе и необходимостью оптимизации субъектной позиции взрослого обучаемого, ускорения его адаптации к новой социальной роли (Г. М. Бурденюк 1999, А. В. Филатова 1999);

7) противоречия, обусловленные различием социального, возрастного статуса и роли обучаемого;

8) противоречия, обусловленные профессиональными и социальными достижениями и необходимостью общаться с преподавателем;

9) противоречия, обусловленные несоответствием общего уровня компетенции в осваиваемой области знаний (А. С. Локосова 2004).

Одной из труднейших проблем глоттодидактики (син. лингводидактики) является типология учеников. В настоящее время нет одной типологии учащихся. В американской, европейской или польской литературе имеются разные подходы к типологии. E. Willis, J. Hause (1993) дают две группы факторов типологии: аффективные (эмоции, мотивировки, личность), 2) когни-

8 Zob. А. Г. Калинина, Индивидуально-ориентировнная модель организации дополнительного образования взросльх по иностранным языкам: на материале английского языка. Автореф. на соиск. ст. канд. педагог. наук., Нижний Новгород 2006. 
тивные (интеллигенция, способности, познавательные стили). К. Bachmajer (1993) представляет типологию учащихся в форме противопоставления: активны - пассивны, собирающие - преобразующие языковые данные, зависимы - независимы от окружения. Н. Komorowska (1999) выдвигает типологию по трем группам факторов: 1) модальности (обладающие хорошей зрительной памятью, обладающие хорошей слуховой памятью, кинестатики), 2) личности (экстравертики или интровертики, с пониженной или повышенной самооценкой, рискующие или нет), квалификации (хорошие или слабые). W. Pfeiffer (2001) констатирует, что пока нет обоснованных данных относительно языковых способностей. Он считает, «что существуют специфические, индивидуальные языковые способности».

Проблемы типологии учащихся явились импульсом к появлению в иноязычной дидактике проблемы автономизации учащегося, которая привела, в частности, к групповой организации обучения (в парах, тройках, четверках, всей группой). Однако автономизация является, пока, сложным процессом и должна применяться вдумчиво.

Данные современной науки (генетики, физиологии, педагогики) свидетельствуют о том, что не бывает двух одинаковых людей. Каждый человек уже от рождения имеет свою психологическую структуру (В. Д. Тимаков 1973).

Следует особо учитывать эмоциональный фактор в жизнедеятельности взрослых. Личная и общественная жизнь взрослого всегда вызывает те или иные эмоции: радость и горе, уверенность или тревогу и страх. Информация и эмоции тесно переплетены в сознании человека. При этом «аккомпанемент эмоции звучит в человеке всю его жизнь», ...«человек живет в мире понятий, как композитор - в мире звуков, как писатель - в мире своих героев. Эмоциональная структура мира понятий у него неповторима, в ней своеобразие его характера, и его опыт, его знания, и его невежество» (Г. Ф. Хильми 1970). Поэтому при обучении взрослых иностранным языкам появляются трудности, которые не встречаются у школьников и студентов: чрезмерное волнение, повышенное чувство стыда из-за собственного незнания, что вызвано, например, артикуляционными трудностями или несовершенством памяти. Словом, роль ученика дается с трудом.

Вместе с тем, есть у взрослых и положительные факторы, которые не встречаются у школьников и студентов:

1) сильная мотивация владеть иностранным языком;

2) активное, положительное отношение к иностранному языку как таковому, склонность заниматься им с увлечением; 
3) наличие ряда характерных черт: трудолюбие, организованность, самостоятельность, целеустремленность, настойчивость, а также устойчивых интеллектуальных свойств;

4) наличие во время учебы благоприятных для ее выполнения состояний (состояние заинтересованности, хорошего психического самочувствия и т.д.);

5) определенный фонд знаний, умений и навыков в области стратегии обучения;

6) определенные индивидуальные и психологические особенности в сенсорной и умственной сферах, отвечающие требованиям данной деятельности.

Однако кроме сильной мотивации к изучению иностранного языка, у них есть и отрицательные факторы: недостаток времени на учебу, нерегулярное посещение занятий, привычка к определенным технологиям обучения, страх быть смешными и критикуемыми.

Все это надо иметь в виду, а не видеть прогресс в обучении лишь в модернизации материально-технической базы. В этом отношении характерно высказывание Н. Коупленда (1958): «Сейчас психологи пришли к общему мнению, что человек использует только 10\% своих физических и умственных способностей. Разница между той силой, которую он использует, и той, которая действительно имеется в его распоряжении, - это разница между тем, что он есть, и тем, кем он может быть».

Однако помимо наличия индивидуальных особенностей у каждой отдельной личности есть общие, характерные, свойственные взрослым.

Обучение этого контингента иностранному языку нельзя начинать без глубокого анализа их возрастных и психологических особенностей. «Фактор возраста», рассматриваемый как единство влияния роста, общесоматического и нервно-психологического созревания в условиях воспитания и жизнедеятельности человека, очень важный. Возраст имеет два основных параметра: время как метрическую характеристику и время как типологическую характеристику, определяющую особенности развития тех или иных качеств в общем процессе развития.

Годы есть, в основном, метрическая характеристика, но вместе с тем, когда речь идет о жизни человека, то говорят, что годы его жизни есть не только количество прожитых лет, но и его жизненный путь, наполненный содержанием (Е. И. Степанова 1974). В литературе анализируются разные подходы и классификации возрастов зрелости. Согласно нашему подходу зрелый возраст имеет два периода: первый - 22-35 лет (мужчины), 
21-35 лет (женщины) и, второй - 36-60 лет (мужчины), 36-60 лет (женщины).

Тенденции в развитии интеллекта, мышления, внимания или памяти у взрослых заслуживают самого пристального внимания и анализа. Наше внимание не сосредоточено лишь на какой-то группе (профессия, образование), а рассматривается шире, поскольку: 1) многие факторы психики присущи вообще взрослым, 2) специфические черты дипломированного специалиста приобретаются постепенно.

Развитие интеллекта взрослых в зависимости от возраста изучались различными учеными. Исследовались как вербальные и общие показатели интеллекта, так отдельные интеллектуальные свойства. Полученные результаты дают основание сделать вывод о том, что при обучении этого контингента иностранному языку необходимо учитывать, что: 1) уровень интеллектуального развития находится в прямой зависимости от уровня образования; структурные изменения интеллекта в зависимости от уровня образования должны особенно приниматься во внимание при обучении языку; 2) показатель вербального интеллекта выше показателей невербального, и этот разрыв в уровне увеличивается параллельно с уровнем образования (развитие интеллекта происходит, прежде всего, за счет развития вербально-логических структур; 3) с завершением созревания организма не заканчивается интеллектуальное развитие, оно продолжается развиваться и дальше в разные периоды зрелости, однако различными темпами.

Интеллектуальные функции память, внимание, мышление и интеллекта в целом претерпевают изменения в разные периоды зрелости.

Однако можно выделить общие периоды и черты в развитии интеллектуальных функций:

a) 22-25 - подъем в уровне памяти и мышления;

б) 26-29 лет - подъем в уровне внимания и спад в уровне памяти и мышления;

в) 30-33 года - высокий уровень развития памяти, мышления и внимания;

г) 34-40 лет - спад и потом незначительный подъем в уровне памяти, мышления и внимания (Д. Н. Борисова 1974, J. Zaniewski 1980).

Можно сказать, что вместе с возрастом в разные периоды зрелости интеллект приобретает компактную целостную систему, а мышление и память развиваются все более взаимообусловлено и взаимозависимо. Поэтому войдя в систему, вновь приобретенные знания по иностранному языку начинают служить в дальнейшем основой для усвоения качественно и количественно нового лексического и грамматического материала. В систему знаний входит особенно та информация, которая является объектом внима- 
ния и понимания. Легко устанавливается связь нового языкового материала со старым, тем более, если он связан с профессиональной деятельностью и интересами обучаемых.

Возможности интеллектуального развития человека в различные периоды его зрелости должны учитываться с целью интенсификации и индивидуализации процесса обучения.

Мышление. В анализе мышления, функция которого состоит в переработке и преобразовании полученной извне информации, принято выделять три периода: 1) предметное, наглядно-действенное, 2) наглядно-образное, 3) вербально-логическое, или понятийное.

В психологической литературе не получил пока достаточного освещения вопрос о динамике развития мышления взрослых; отсутствует единое мнение относительно расположения оптимальных возрастных точек развития мыслительных функций.

Анализ экспериментальных данных показал, что во всех возрастных группах зрелости (22-40 лет) обнаруживается общая тенденция, проявляющаяся в несовпадении образного, вербально-логического и практического мышления (см. табл. 1).

Таблица 1. Соотношение моментов развития мышления (22-40 лет) ${ }^{9}$

\begin{tabular}{|l|l|l|l|}
\hline \multicolumn{1}{|c|}{ Виды мышления } & \multicolumn{1}{|c|}{$\begin{array}{c}\text { Повышение } \\
\text { функционального } \\
\text { уровня }\end{array}$} & $\begin{array}{c}\text { Стабилизация } \\
\text { функционального } \\
\text { уровня }\end{array}$ & $\begin{array}{c}\text { Понижение функции } \\
\text { функцинального } \\
\text { уровня }\end{array}$ \\
\hline $\begin{array}{l}\text { Практическое } \\
\text { мышление }\end{array}$ & $\begin{array}{l}20-23,25,27,31,32, \\
34,38\end{array}$ & $20,35,39$ & $21,24,26,30,33,36,37$ \\
\hline $\begin{array}{l}\text { Образное } \\
\text { мышление }\end{array}$ & $20,23,25,30,32,35,39$ & $\begin{array}{l}27-28,35-36,37-38, \\
39-40\end{array}$ & $22,24,26,31,34$ \\
\hline $\begin{array}{l}\text { Вербально- } \\
\text { - логическое } \\
\text { мышление }\end{array}$ & $23,25,32,33$ & от 27 до 31, от 34 до 40 & $22,23,24$ \\
\hline
\end{tabular}

Из таблицы 1 видно, что наибольшие изменения происходят в возрасте до 25 лет. Наблюдается неравномерное соотношение образного, вербально-логического и практического мышления. В эти годы обнаруживается высокий уровень вербально-логического мышления. С 26 лет вербально-

9 Za: Е. И. Степанова, Возрастные особенности взросльх, [w:] Возрастнье особенности умственной деятельности взрослых, Е. И. Степанова (red.), Ленинград 1974; J. Zaniewski, Podstawy nauczania języka rosyjskiego jako obcego pracowników nauki (medycyny). (Zasady, dobór jezzkowy, etapy i formy), Białystok 1980. 
-логическое мышление начинает развиваться более равномерно (без резких подъемов и спадов), тогда как образное и практическое мышление начинает подвергаться большим изменениям. По всей вероятности, устойчивость вербально-логического мышления взрослых можно объяснить структурными преобразованиями, которые происходят во взаимосвязи между видами мышления.

Отсюда вытекают определенные практические выводы. Чтобы упрочились связи между образными и вербально-логическими компонентами мышления, между механической и смысловой памятью в учебной работе с взрослыми следует стремиться разнообразить использование средств наглядности, сочетая изображения, схемы и графики с объектами ${ }^{10}$.

Внимание. Не менее важны вопросы возрастных особенностей внимания взрослых. Внимание человека имеет отражение в сенсорных, двигательных, интеллектуальных процессах и непосредственно включено в его поведение, в его повседневную и профессиональную деятельность. Особенно весомое значение приобретает внимание в познавательной (обучающей) деятельности человека, а тем более для эффективности познавательной деятельности. Образно говоря, внимание есть именно та дверь, через которую проходит все, что только входит в душу человека из внешнего мира.

Разнообразные и многогранные качественные характеристики внимания получили в психологии название свойств или сторон внимания, которые находятся в тесной связи и взаимообусловленности в психической деятельности: объем, устойчивость, концентрация, распределение и изобразительная целенаправленность. Это центральные характеристики внимания.

Экспериментальные данные по выявлению особенностей развития внимания у взрослых, дают основание заключить, что эффективность интеллектуальной деятельности взрослых в разные периоды зрелости обусловливается свойствами внимания в разной степени. Именно эти свойства и особенности развития внимания взрослых играют ключевую роль в обучении иностранному языку. Так, например, полученные данные говорят, что усвоение большой по объему иноязычной порции материала учащимися до 33 лет вполне возможно. Этому будут способствовать условия частого и быстрого переключения внимания с одного вида речевой деятельности на другой (одновременное слушание, записывание и говорение). Это происходит в сочетании с опорой на важность изучаемого материала и интересы обучающихся, что интенсифицирует избирательную направленность их деятельности.

10 В. П. Зинченко, В. М. Мунипов, 1972. 
После 35 года жизни, как правило, способность к быстрому и легкому переключению внимания постепенно снижается, уменьшается объем и становится слабее избирательная его направленность, слабеет устойчивость и концентрация. Обучение иностранным языкам в более поздние периоды зрелости (35-40 лет) должно организоваться с учетом определенного ослабления регулирующего влияния свойств и параметров внимания. Особенно стимулирующий и прогрессивный характер носят возрастные изменения функции разных видов внимания в возрасте 22-33 лет, а с 34-летнего возраста констатируется некоторое снижение уровня внимания.

Повышение, стабилизацию или понижение функционального уровня свойств внимания (объем, переключение, устойчивость, избирательность и концентрация) в разные периоды жизни взрослого человека (22-40 лет) характеризует следующая таблица (см. Таб. 2).

Таблица 2. Свойства внимания ${ }^{11}$

\begin{tabular}{|l|c|c|c|}
\hline \multicolumn{1}{|c|}{$\begin{array}{c}\text { Свойства } \\
\text { внимания }\end{array}$} & $\begin{array}{c}\text { Повышение } \\
\text { функционального } \\
\text { уровня }\end{array}$ & $\begin{array}{c}\text { Стабилизация } \\
\text { функционального } \\
\text { уровня }\end{array}$ & $\begin{array}{c}\text { Понижение } \\
\text { функцинального } \\
\text { уровня }\end{array}$ \\
\hline Объем & $26-33$ & $22-25$ & $34-40$ \\
\hline Переключение & $27-33$ & $22-25$ & $26,34-40$ \\
\hline Устойчивость & - & $22-34$ & $35-40$ \\
\hline Избирательность & $22-26,27-33$ & $34-40$ & $36-40$ \\
\hline Концентрация & $25-33$ & $22-24$ & $34-40$ \\
\hline
\end{tabular}

Итоги исследований, экспериментов и наблюдений над учебной деятельностью взрослых, изучающих иностранные языки, дают возможность констатировать, что у них осуществляется глобальная перестройка внимания, обусловливающая усиление роли внимания в ходе произвольной регуляции психической деятельности человека в различные периоды его зрелости.

Память. В современных исследованиях память изучается в разных аспектах и на разных ярусах. В одних работах изучают социально-историческую и процессуальную природу памяти, в других - биохимическую, в третьих - функциональную или объясняют механизмы памяти на

11 Л. Н. Фоменко, Возрастные особенности внимания взросльх, [w:] Возрастные особенности умственной деятельности взросльх, Е. И. Степанова (red.), Ленинград 1974; J. Zaniewski Podstawy nauczania języka rosyjskiego jako obcego pracowników nauki (medycyny). (Zasady, dobór jezzykowy, etapy i formy), Białystok 1980. 
основе нейрофизиологических данных ${ }^{12}$. Однако во всех случаях предметом внимания авторов являются три характеристики памяти - запоминание, сохранение и воспроизведение. Этот аспект заслуживает рассмотрения, тем более, что долгое время считалось, что развитие памяти как функции заканчивается в период обучения и биологического созревания организма, а у взрослых развитие памяти не происходит. Но оно происходит ${ }^{13}$.

У большинства людей, продолжающих работать и упражнять свою память, она еще долго - до 50-55 лет - при нормальных условиях остается почти на одном уровне ${ }^{14}$. Даже память 70-90-летнего человека найдет возможность запомнить что-то новое.

Согласно современным представлениям, существует кратковременная память, долговременная ${ }^{15}$ (перманентная) и непосредственная или мгновенная память, продолжительность которой несколько секунд после поступления в мозг информации. Эта последняя память, как правило, впоследствии не оставляет никакого следа.

Считается, что в основе кратковременной памяти лежит особый механизм, функция которого состоит в «классификации материала» по сенсорным качествам, в отличие от долговременной памяти, в которой материал организуется по смыслу. Содержание кратковременной памяти быстро распадается, так что оно оказывается почти полностью стертым после регистрации восьми - десяти новых объектов или через 10-20 секунд (Д. Брондент 1966).

Материал более прочно и больший срок хранится в долговременной памяти, но вероятность того, что он попадает в нее из кратковременной памяти, зависит от внимания, которое ему уделяется, и от типов операций, которые совершаются над ним. По другим данным, кратковременная память - такой вид памяти, где полный цикл получения, сохранения и использования информации длится от нескольких секунд до нескольких минут (П. Х. Линдсей, Д. А. Норман 1972). Любая информация извне поступает в организм через систему кратковременной памяти. Таким образом,

12 См. К. Прибрам 1968, А. Р. Лурия 1973, Е. М. Гуровиц 1973 и др.

13 В. Я. Ляудис 1970, Н. Д. Никандров 1970.

14 По подсчетам многих ученых, мозг человека насчитывает 10 миллиардов нервных клетокнейронов, а каждая клетка имеет до 10 тысяч прямых связей с другими нейронами. Количество нервных путей в мозге столь велико, что оно не может исчерпаться за нормальную жизнь человека.

15 Кратковременная память, (STM) (англ. Short-term memory) является первым этапом трансформирования информации. Долговременная память (LTM) (англ. Long-term memory) является хранилищем кодированных следов памяти с неограниченной ёмкостью во времени и пространстве. 
кратковременная память является основным начальным звеном переработки информации.

Объем кратковременной памяти, выраженный в буквах, равен единицам, а в словах - 7. Оперирование словом как более крупной единицей уменьшает число единиц, значительно увеличивая объем содержащейся в них информации. В 7 словах количество информации, выраженной в двойных символах, равно 33 битам, а в буквах - 26 битам. В кратковременной памяти может храниться 5,58 абстрактных слов, 5,86 - конкретных, а также 1,75 простого предложения, т.е. примерно 10.5 организованных слов. Следовательно, перекодируя информацию в более крупные единицы-слова, а затем в предложения, человек увеличивает объем кратковременного хранения, облегчая при этом оперирование информацией.

Поскольку непосредственная память обладает пропускной способностью 13-15 бит/сек. и емкостью 150 бит, она может сохранять воспринимаемые сведения 10-15 сек., после чего большая часть информации теряется, а меньшая со скоростью 0,5 бит/сек. переходит в кратковременную память, где хранится 24-48 часов. Зато емкость кратковременной памяти значительно больше.

С еще меньшей скоростью (0,05 бит/сек.) информация переходит в долговременную память, где почти $40 \%$ ее хранится в течение всей жизни человека. Емкость долговременной памяти для всех практических целей можно считать безграничной (Н. Л. Никандров 1970).

Если считать, что среднее содержание информации в учебном понятии соответствует 50 битам, то для перехода информации в кратковременную память необходимо около 100 сек. (50: 0,5 = 100). Как утверждают психологи, человек может интенсивно работать в среднем 30 мин. непрерывно (т.е. 1800 сек.). За это время можно выучить около 18 понятий $(1800: 100=18)$.

При переходе информации в кратковременную память её информационное содержание значительно уменьшается (примерно до 15 бит, вместо 50). Это значит, что за 30 мин. примерно 6 понятий могут перейти в долговременную память. При повторении через 2-6 недель примерно на 2/3 пройденного материала переходит в долговременную память практически навсегда.

Оценивая в целом развитие долговременного вербального запоминания с 22 до 40 лет, можно выделить период с 22 до 35 лет как период сенситивного развития. Это означает, что в возрастном диапазоне 22-35 лет наиболее высокоразвито долговременное вербальное запоминание. Однако этот период заканчивается раньше на пять лет.

О высоком уровне развития смысловой памяти в пожилом возрасте у людей, продолжающих активную интеллектуальную деятельность, свиде- 
тельствуют также лабораторные данные ${ }^{16}$. Развитие памяти у взрослых не носит сплошного подъема или сплошного спада, а развитие памяти продолжается и после биологического созревания, которое обычно происходит к 18-24 годам. С более высоким уровнем развития памяти связаны два микровозрастных периода - 18-24 и 23-33 года. Эти периоды могут быть названы фазами сенситивного развития памяти. Однако, более высокий (выше среднего) уровень развития памяти наблюдается у 18-24-летних.

На уровне среднего развития памяти находятся 29-33-летние. Другие два макропериода (25-28 и 34-40 лет) имеют уровень ниже среднего. Механизмом этих изменений являются структурные преобразования в мнемической функции. Характерной чертой памяти у взрослых является, прежде всего, заметный перевес логического и опосредованного по сравнению с механическим и непосредственным запоминанием.

Наш опыт показывает, что продуктивность запоминания у взрослых была высокой в тех случаях, когда они могли устанавливать логические связи в предлагаемом им учебном материале. Когда же они не могли найти смысловой опоры и запоминали материал без неё, у них появлялись заметные трудности, а продуктивность в таких случаях была относительно небольшой.

На процесс запоминания нового материала оказывает также большое влияние то, что это новое как бы «вплетается» в систему тех знаний, которыми обладают обучаемые. Ранее усвоенные ими знания имеют строго систематизированный характер и представляют собой довольно прочно сформированный фундамент. Запоминание - это весьма активный и творческий процесс, оно обязательно включает в себя глубокое продумывание, переработку и перестройку материала. Неестественной, вызывающей внутренний протест и затруднение, является для них задача запомнить чтолибо чисто механически и неосмысленно. Это связано с резко выраженной профессиональной направленностью памяти.

Можно с уверенностью сказать, что наиболее прочно и глубоко сохраняются в памяти у взрослых те части материала, которые связаны с решением ими намеченных задач, а также то, что как бы «выношено», передумано и пережито ими, что стало неотъемлемой частью их жизненной деятельности.

До настоящего времени в литературе не получили достаточного освещения вопросы, связанные с изучением на занятиях по иностранному

16 См. Исследования, лаборатории А. А. Смирнова полученные 3. И. Истоминой, В. В. Самохваловой и И. Н. Преображенской (1967). 
языку возможностей учащихся запоминать увеличенные дозы лексики ${ }^{17}$. Однако, оценивая память того или иного обучаемого, мы должны иметь в виду наличие у него каких-то еще не обнаруженных возможностей, компенсаторных свойств, повышающих объем и продуктивность памяти.

Из выше сказанного (о памяти) вытекают некоторые методические выводы при обучении взрослых:

- у обучаемых, имевших перерыв в изучении иностранного языка, важно обращать внимание на развитие долговременной вербальной памяти;

- предусматривать различные виды работы по запоминанию нового словесного материала;

- процесс обучения необходимо организовать с опорой на произвольное, сознательное запоминание языкового материала;

- повторения материала через 2-4 недели имеет весьма существенное значение для долговременного запоминания.

Для достижения высокой результативности обучения предлагаются различные пути. В частности, необходимыми условиями считаются следующие:

1) если обучение будет построено при активном участии обучаемых в определении целей и содержания образовательного процесса, его организации, планировании и контроля;

2) если учебные группы будут сформулированы с учетом разных познавательных стилей взрослого контингента обучающихся, в соответствии с которыми будет использован оптимальный вариант технологии обучения;

3) если обучение иностранным языкам взрослых по разным вариантам будет включать социокультурный компонент, необходимый для повышения мотивированности обучающихся и формирования готовности к межкультурному общению (А. Г. Калинина 2006);

4) если соблюдаются ведущие принципы андрагогики: приоритет самостоятельного обучения; принцип совместной деятельности; опора на опыт; индивидуализация; системность обучения; контекстность обучения; актуализация результатов обучения; эклективность обучения; развитие образовательных потребностей;

17 Анализ разных аспектов памяти выдвигает проблему измерения объема и уровня памяти. Поэтому с целью ориентировочной диагностики уровня развития мнемической функции памяти можно использовать референтный фактор по изучению 8 бессмысленных слогов в предложенном порядке. Количество повторений будет тестом оценки уровня памяти: 2-4 повторений - отличная память; 5-10 повторений - хорошая память; 11-15 повторений удовлетворительная память; 16-20 повторений - плохая память. 
5) если процесс обучения английскому языку проводится в форме деловой игры, включающей ситуации опосредствованного общения и учитывающей уровень развития слушателей (опыт, знания, интересы, потребности, чувства, эмоции, мировоззрение (Е. П. Рыжикова 2001).

Проводимые исследования позволили выработать рекомендации для преподавателей, работающих во взрослой аудитории:

- нарядус традиционным лингвистическим тестированием, необходимо проводить психологическое анкетирование для выявления оптимальных форм и методов обучения иностранным языкам;

- необходимо привлекать взрослых обучающихся к отбору содержания обучения, которое должно соответствовать целям обучающихся и быть направлено на обучение преимущественно устному общению или чтению профессионально-ориентированных текстов;

- целесообразнопредлагать пробныезанятия с использованием разных технологий обучения для определения наиболее эффективного стиля изучения иностранного языка;

- максимально использовать в процессе обучения аудиовизуальные, аутентичные материалы, компьютеры, Интернет и мультимедиальные средства (А. Г. Калинина 2006).

Эффективность обучения взрослых целесообразно организовывать с учетом следующих положений:

1. Интенсивность проявления психологических барьеров в процессе изучения иностранного языка и степень их влияния на успешность обучения обусловливаются характером индивидуальной стратегии внутренней и внешней активности взрослого в ситуации затруднения.

2. Преодоление и компенсация психологических барьеров в изучении иностранного языка взрослыми возможно при включении обучающихся в специально сконструированную программу психологического сопровождения процесса освоения иноязычной реальности взрослыми обучающимися (А. С. Локосова 2004).

3. Потенциальными детерминантами возникновения объективных психологических барьеров выступают: а) характеристики когнитивной сферы: свойства внимания, характеристики памяти, уровень сформированности языковых механизмов; б) особенности мотивационной сферы: выраженность ориентации на успех или избегание неудач, интенсивность потребности в достижении, сила потребности в освоении иностранного языка, содержание мотивов изучения иностранного языка. 
4. Эффективность изучения иностранного языка взрослыми повышается при включении их в специально разработанную коррекционно-развивающую программуза счет усиления внутренней мотивации, повышения самооценки компетентности в изучении иностранного языка, формирования умений прогнозирования и проектирования развития внутреннего потенциала в преодолении психологических барьеров (А. С. Локосова 2004).

5. Эффективность реализации андрагогической поддержки взрослых в процессе обучения иностранному языку обеспечивается на основе реализации следующих дидактических условий:

- учет индивидуальных затруднений и субъективного образовательного опыта взрослого;

- практико-ориентированный характер содержания обучения, который отвечает целям и потребностям взрослых обучающихся;

- интегрирование индивидуальной, групповой и коллективной (фронтальной) форм учебной деятельности;

- применение игрового и проблемного методов обучения;

- взаимосвязь и взаимообусловленность контроля и самоконтроля результатов учебной деятельности обучающихся (Х. Коморовска 2003).

\section{Библиография}

Ананьев Б. Г., Некоторые проблемы психологии взрослых. Москва 1972.

Барвенко О. Г., Психологические барьеры в обучении иностранному языку взрослых. Автореф. дисс. на соиск. уч. ст. канд. педаг. наук. Ставрополь 2004.

Борисова Л. Н., Динамика интеллектуального развития взросльх, [w:] Возрастные особенности умственной деятельности взрослых, Е. И. Степанова (red.), Ленинград 1974.

Брогндент Д., Современные исследования кратковременной памяти, „Вопросы психологии” 1966, № 3.

Бурденюк Г. М., Управление самостоятельной учебной деятельностью при обучении иностранным языкам взрослых. Автореф. дисс. на соиск. уч. ст. докт педаг. наук., Йошкар-Ола 1999.

Витлин Ж. Л., Проблемы обучения взрослых иностранному языку /грамматические аспекты проблемы/: Дисс. докт. педаг. наук., Москва 1983.

Возрастная психология взрослых. (Теоретическая и прикладная). Тезисы докладов к научной 
конференции 27-29 октября 1971, Б. Г. Ананьев (red.).

Заневский Я., Лингводидактические основы обучения русскому языку как иностранному научных работников. (Приниипы, языковое содержание обучения, этапы и виды речевой деятельности). Афтореф. дисс. на соиск. уч. ст. докт. педагог. наук., Москва 1984.

Калинина А. Г., Индивидуально ориентированная модель организации дополнительного образования взрослых по иностранным языкам: на материале английского языка. Автореф. дисс. На соиск. уч. ст. канд. педаг. наук., Нижний Новгород 2006.

Климентьев Д. Д., Методические основы автономного компьютерного обучения взрослых чтению на английском языке. Начальный этап. Автореф. дисс. на соиск. уч. ст. канд. педагог. наук., Курск 1999.

Локосова А. С., Изменение мотвационно-ценностной сферы тичности взрослых профессионалов в ходе обучения деловому английскому языку: на материале слушателей Президентской программы. Автореф. дисс. на соиск. уч. ст. канд. педагог. наук., Ростов-на-Дону 2004.

Лукошкина И. Л., Методические принципы создания профессионально оринтировнных автономных обучающих компьютерных курсов для взрослых по чтению на иностранном языке. На примере франиузского языка. Автореф. дисс. на соиск. уч. ст. канд. педагог. наук., Москва 2001.

Мирошникова Н. Н., Оптимизация отбора и организации учебного материала для обучения взрослых английскому языку: в условиях языковых курсов. Автореф. дисс. на соиск. уч. ст. канд. педагог. наук., Санкт-Петербург 2003.

Нижнева Н. Н., Творчество в процессе обучения иностранным языкам, Москва 1993.

Нижнева Н. Н., Пособие по обучению для 4-5 курсов, Минск 1993.

Нижнева Н. Н., Научныцй дискурс - Scientific discourse: практикум, Минск 2011.

Рыжикова Е. П., Научно-педагогические условия изучения иностранного языка в системе андрогогики. Автореф. дисс. на соиск. уч. ст. канд. педагог. наук., Москва 2001.

Степанова Е. И., Возрастные особенности взрослых, [w:] Возрастные особенности умственной деятельности взрослых, Е. И. Степанова (red.), Ленинград 1974.

Тимаков В. Д., Волчков Н. П., Специальные проблемы генетики человека, „Вопросы психологии" 1973, № 6.

Филатова А. В., Дидактические условия реализации андрагогической поддержки взрослых в процессе обучения иностранному языку. Автореф. дисс. на соиск. уч. ст. канд. педагог. наук., Йошкар-Ола 1999.

Фоменко Л. Н., Возрастные особенности внимания взрослых, [w:] Возрастные особенности умственной деятельности взрослых, Е. И. Степанова (red.), Ленинград 1974.

Энииклопедический словарь медииинских терминов, Т. 1, Москва 1982.

Komorowska H., Metodyka nauczania języków obcych, Warszawa 2002.

Lindsay P. H., Norman D. A., Human Information Processing, New York 1972.

Markunas A., Базовые категории педагогики, Poznań 2006.

Markunas А., Элементарные концепты педагогической психологии. Компендиум для филологов, Poznań 2007. 
Nauczanie języków obcych - Polska a Europa, H. Komorowska (red.), Warszawa 2007.

Nizhneva-Ksenafantava N., Aspekt lingwistyczny doskonalenia kultury językowej studentów $z$ wykorzystaniem zadań kreatywnych, Białystok 2009.

Pfeiffer W., Nauka języków obcych. Od praktyki do praktyki, Poznań 2001.

Zaniewski J., Podstawy nauczania języka rosyjskiego jako obcego pracowników nauki (medycyny). (Zasady, dobór językowy, etapy i formy), Białystok 1980. 